\title{
A Study of Creativity of Secondary School Children as a Correlate of Some Television Viewing Habits
}

\author{
Ravi Kant \\ Assistant Professor in Education,Maulana Azad National Urdu University, \\ College of Teacher Education,,Darbhanga (Bihar) 846001 \\ edu.ravikant@gmail.com
}

\begin{abstract}
The present study was undertaken to study of creativity in relation to $\mathrm{TV}$ viewing habits of secondary school students. The sample consists of 400 secondary school students of Rampur city. Verbal test of creativity and TV viewing habits questionnaire were used for this investigation. The result of this study shows that on some behalf TV viewing is negatively related to creativity but overall $\mathrm{TV}$ viewing is positively related to creativity of secondary school students. Students viewed variety type program on TV however they were low achiever or high achiever gain knowledge and information through TV. In this study relationship between creativity and TV viewing was positive overall but non significant.
\end{abstract}

Index Terms - Creativity, Television viewing, Academic achievement, Secondary school students

\section{INTRODUCTION}

Today it is very common in India for a household to have at least one television. In fact, it is so common that it is difficult to imagine a household without Television. In these days television has become the most popular type of communication and entertainment. Because of its popularity, television clearly has a far-reaching effect on human life in particular on student's behavior. It is already proved that learning through multisensory organ, has a great impact with long time stability.

There has been a controversy between educationist and media persons as to whether TV should be used for enrichment, entertainment or for formal education. In other words should the role of TV are finally examined? Much researches show that TV influenced children minds very much. Students get many advantages from TV programs. They can increase their knowledge from TV. They get many experiences from TV. Schmidt etal. $(2008)^{1}$ in his research found that educational television is linked positively with academic achievement. Kirkorian $(2008)^{2}$ in his research explored that well designed; age-appropriate, educational television can be beneficial for children of preschool age. Wyatt $(2006)^{3}$ in her study found that the amount of television hours watched is almost always not significantly associated with reading test scores of African American students and always associated with reading test scores for white students. Shejwal (2006) ${ }^{4}$ finds in his study that the long hours spent in TV viewing not only adversely affected the subject's academic growth and cognitive development, but also did not contribute towards the development of their academic skills and abilities. Arya, Kalpna (2004) $)^{5}$ find that the average time spent in front of television were found to be 1 to 3 hours. Results also show that knowledge value of children increase due to television and makes had better knowledge value than females. Whether they were cable network or Doordarshan viewers. Krosrick $(2003)^{6}$ in his study found that television viewing frequency was related to social integration with peers, intelligence, book reading and the hostility of parental punishment methods. Hershberger $(2002)^{7}$ found that the greater extent of TV viewing among students, the lower was their school performance. Taj and Masthan $(1998)^{8}$ stated that TV is the most effective modern device which has conquered the imagination of any person of any perspective. It is fact that despite there is several rudimentary and modern techniques of mass communication responsible for several modern perspectives. TV has gained an edge over all of them and has risen beyond in the imagination of knowledge. Kaur J (1998) ${ }^{9}$ stated that television is a potent medium of information, education and entertainment. It is one of the most significant technological developments for the uplift of the society. The viewing of TV has influenced the social life of both urban and rural adults. Agarwal Sunita (1998) ${ }^{10}$ found that TV expose helped in awareness building and make them conscious about their rights and status. The study also revealed that sex, violence and offensive language made a negative impact on the viewer. This work strengthens the point that educational technology should compact the negative impact of media. Thus Gyan Darshan has special role to play.

Creativity is as old as human history. It is creativity on the part of man that distinguishes human being from animals. It is potential which influences human activity in almost all the spheres of life express one's inner self. Creativity is one of the cognitive functions which contribute to socio biological adaptation. It can be defined as the ability that allows the production of new or unusual associations among known ideas or concepts. 
These words highlight those aspects most relevant to the creative process the elaboration of information through contrast and caparison of data and the acquired knowledge. Padma and Yadav $(2005)^{11}$ investigate that emphasis in rational, social and interpersonal aspect rather than cognitive, analytical and utilitarian aspect of creativity. The results also indicated gender differences. Isen $(2000)^{12}$ shows that a positive mood promotes a tendency towards greater creativity and flexibility in negotiation and in problem solving as well as more efficiency and thoroughness in decision making. Kaile etal. $(1994)^{13}$ in his investigation found that no significant relationship existed between creativity measures and socio economic status and also creativity had no significant relationship with socio economic status for high, average and low socio economic groups. Raj $(1994)^{14}$ explored that flexibility had significant correlation with verbal and non verbal intelligence. Omkar (1993) ${ }^{15}$ in his study found that the creativity was found to be significantly correlated with family functioning. Bansh $(1993)^{16}$ in his study revealed that creativity could be predicted more precisely by considering the perception of treatment based on principle that expect and demand creative behavior from the students. Pandey etal. (1993) ${ }^{17}$ found in his study that among the upper socio economic status group both elaboration and originality were found to be significantly related to socio economic status.

A burning question raise here that can TV influence the creativity of students? Creativity of students gets affected by matter that they watch on TV. Mark etal.(2009) ${ }^{18}$ in his study examine the relative effects of television verses radio on children's creativity. The result indicated that the two media did not have a differential effect on children's creativity. Keyne $(2003)^{19}$ in his investigation found that parents may improve children's creativity level by limiting the time children spend on TV viewing to prevent displacement effect and by stimulating children to choose programs that enhance or at least do not interface with creativity. Singer and Singer $(2001)^{20}$ explored that TV has positive impact on children's creativity. Creativity tasks or imaginative play by enriching the store of ideas from which children can generate when engage in these acts. Then as a result the quality and quantity of their creative products may be improved. MacBath $(1996)^{21}$ in her study suggests that television may be responsible for an increase in children's imagination and creativity. She claims that the role of television can actually boost participation in other activities, such as reading and drawing. It is believed that in persistence and school performance she found in her research.

There is a need to bring about a greater awareness of the tremendous force of television as a permanent institution with in our culture, with potential impact of this force upon the creativity of students. It is the purpose of this study to throw some light on the dark tunnel of television's effect on creative potential.

\section{STATEMENT OF THE PROBLEM}

A study of creativity of secondary school children as a correlate of some television viewing habits

\section{FORMULATED HYPOTHESES}

1. There is no significant relationship between time spent on TV viewing and creativity of high achiever students.

2. There is no significant relationship between time spent on TV viewing and creativity of low achiever students.

3. There is no significant relationship between number of programs viewed and creativity of high achiever students.

4. There is no significant relationship between number of programs viewed and creativity of low achiever students.

5. There is no significant relationship between number of channels viewed and creativity of high achiever students.

6. There is no significant relationship between number of channels viewed and creativity of low achiever students.

\section{OPERATIONAL DEFINITIONS}

A. TV VIEWING HABITS - In this study this terms was categorized as follow.

a) DURATION OF TV VIEWING- The meaning of duration of TV viewing in this study was that time spent in viewing the TV by students.

b) TYPES OF PROGRAMS - Types of programs means variety of programs watched by students. Student who watches a particular type program is consider as uniform type program viewer. Student who watch different variety type program consider as variety type TV program viewer.

B. CREATIVITY - Creativity can be defined as new capacity to do new things. It means to do new work in new way. Creativity can be also defined as new thoughts, new relationships and create unusual ideas.

C. ACADEMIC ACHIEVEMENT - In this study academic achievement means those marks obtained in high school level. Only high school marks of secondary school students will be considered.

\section{POPULATION AND SAMPLE}

In this study stratified random sampling techniques was used. There were many school affiliated to UP board and CBSE educational board. At the first stage of sampling, five schools of UP and CBSE educational board respectively were selected from total schools of 
Rampur city randomly. After this a list was prepared on the basis of student's high school examination marks of UP and CBSE board in ascending to descending order separately for each school. Then top 20 students and bottom 20 students from each school were included in the sample. In next stage top most 100 students and 100 bottom students were selected as high achiever and low achiever from UP and CBSE board. Thus sample was consisting of a high achiever group of 200 students and a low achiever group of 200 students. The high achiever group was consisting of 100 students belonging to CBSE board's schools and 100 students belonging to UP board. In the same manner low achiever group was consisting of 100 students belonging to CBSE board's school and 100 students belonging to UP board schools.

\section{Total Sample}

Students studying in class XI from UP \& CBSE Board Secondary School

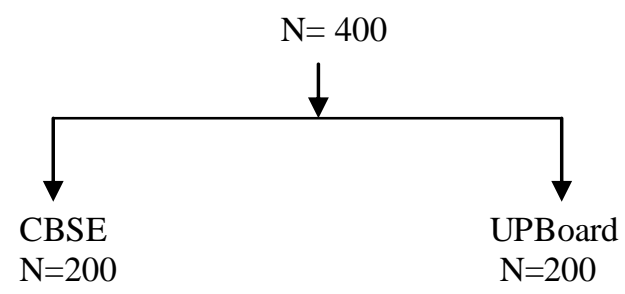

Top 100 students + Top 100 students $=200$ students

Lower 100 students + Lower 100 students $=200$ students

\section{INSTRUMENTS USED}

\section{A. VERBAL TEST OF CREATIVITY}

This test was developed by Dr. Baqer Mehdi, Professor in Education NCERT. The verbal test of creativity includes for sub test namely consequences test, unusual test, similarity test and product improvement test. Test-retest reliability for this test was calculated. $(\mathrm{N}=32)$. The reliability of total creativity scores which came out to be .959 is quite high. Validity of test established and it was found .39 which is significant beyond .01 level. A table has been provided in the scoring sheet to summarize the scores for fluency, flexibility and originality scores obtained by the testee on different activities. The total fluency, flexibility and originality scores have to be entered in the appropriate columns of the table.

\section{B. TV VIEWING HABITS QUESTIONNAIRE}

As factual information and opinion was denied by the researcher in the present study from the students, hence the researcher has employed the tool 'Questionnaire' for the purpose of data collection. The questionnaire to the students was prepared in English and Hindi languages in order to get the maximum responses from the students. The statements were constructed in such a way that students could understand them properly. Since the statements were simple in style and unambiguous in meaning, they were able to respond easily. For scoring time spent on TV viewing student's given time will be converted in to minute for convenience sake. Scoring was done by awarding a score of 5(five) for one program and also 5(five) for one channel viewed by the student.

\section{ANALYSIS AND RESULTS}

Analysis is the process of resolving a problem in the logical sense. Analysis is a general process of breaking down a complex whole in to as many careful distinguished parts as opposed to synthesis so as derive concrete results.

Hypothesis 1- There is no significant relationship between time spent on TV viewing and creativity of high achiever students.

\begin{tabular}{|c|c|c|c|c|}
\hline Variable & $\mathbf{N}$ & Mean & S.D. & $\mathbf{r}$ \\
\hline \multirow[t]{2}{*}{ Time Scores } & 200 & 141. & 72.4 & $-.110 *$ \\
\hline & & 2 & 4 & \\
\hline \multirow[t]{2}{*}{ Creativity } & 200 & 53.7 & 17.3 & \\
\hline & & 6 & 7 & \\
\hline
\end{tabular}

* Not significant

According to table the mean values of time scores and total creativity scores of high achiever students are 141.25 and 53.76 respectively. Standard deviations for time scores and creativity scores are 72.44 and 17.37. The $\mathrm{r}$ value is -.110 . This value is not significant. It means null hypothesis stand accepted.

Hypothesis 2- There is no significant relationship between time spent on TV viewing and creativity of low achiever students.

\begin{tabular}{|c|c|c|c|c|}
\hline Variable & $\mathbf{N}$ & Mean & S.D & $\mathbf{r}$ \\
\hline Time & 200 & 136 & 72. & $+.086^{*}$ \\
\hline Scores & & .2 & 73 & \\
\hline $\begin{array}{l}\text { Creativit } \\
\mathrm{y}\end{array}$ & 200 & $20^{44 .}$ & $24^{15 .}$ & \\
\hline
\end{tabular}

$*$ Not significant

The mean values of time scores and total creativity scores of low achiever students are 136.20 and 44.20 respectively. Standard deviations for time scores and creativity scores are 72.73 and 15.24 . The $r$ value is 
+.086. This value is not significant. It means null hypothesis stand accepted.

Hypothesis 3- There is no significant relationship between number of programs viewed and creativity of high achiever students.

Table 1.3 Means, standard deviations and $r$ value showing the relationship between programs viewed and creativity of high achiever students.

\begin{tabular}{ccccc}
\hline Variable & N & Mean & S.D. & r \\
\hline Programs Scores & 200 & 43.0 & 20.6 & $+.083^{*}$ \\
Creativity & 200 & 53.7 & 17.3 & \\
\hline * Not significant & & & &
\end{tabular}

The mean scores of programs viewed and creativity of high achiever students are 43.02 and 53.76 respectively. The standard deviations for both variables are 20.66 and 17.37 respectively. Correlation value between both variables is +.083 which is not significant. So null hypothesis stand accepted.

Hypothesis 4- There is no significant relationship between number of programs viewed and creativity of low achiever students.

Table 1.4 Means, standard deviations and $\mathrm{r}$ value showing the relationship between programs viewed and creativity of low achiever students.

\begin{tabular}{ccccc}
\hline Variable & N & $\begin{array}{c}\text { Me } \\
\text { an }\end{array}$ & S.D. & r \\
\hline Programs Scores & 200 & 37.2 & 17.5 & $+.030^{*}$ \\
Creativity & 200 & 44.2 & 15.2 & \\
\hline
\end{tabular}

*Not significant

According to table 4.07 the mean values of programs viewed and total creativity scores of low achiever students are 37.26 and 44.20 respectively. Standard deviations for programs scores and creativity scores are 17.56 and 15.24 . The $r$ value is +.030 . This value is not significant. It means null hypothesis stand accepted.

Hypothesis 5- There is no significant relationship between number of channels viewed and creativity of high achiever students.

Table 1.5 Means, standard deviations and $r$ value showing the relationship between channels viewed and creativity of high achiever students.

\begin{tabular}{ccccc}
\hline Variable & N & Mean & S.D. & r \\
\hline Channels Scores & 200 & 62.0 & 39.0 & $+.006^{*}$ \\
Creativity & 200 & 53.7 & 17.3 & \\
\hline
\end{tabular}

*Not significant

The mean values of channels scores and creativity scores of high achiever students are 62.05 and 53.76 respectively. Standard deviations of above said variable are 39.07 and 17.37 respectively. Correlation coefficient value is +.006 . This value is positive and not significant. Thus null hypothesis stand accepted.

Hypothesis 6- There is no significant relationship between number of channels viewed and creativity of low achiever students.

Table 1.6 Means, standard deviations and $r$ value showing the relationship between channels viewed and creativity of low achiever students.

\begin{tabular}{ccccc}
\hline Variable & N & Mean & S.D. & r \\
\hline Channels Scores & 200 & 57.4 & 32.7 & $-.102^{*}$ \\
Creativity & 200 & 44.2 & 15.2 & \\
\hline
\end{tabular}

*Not significant

Table shows that mean values of low achiever student's channels scores and creativity scores are 57.45 and 44.20 respectively. Standard deviations of both groups are 32.79 and 15.24 respectively. Correlation coefficient $r$ is -.102 which is not significant. It means null hypothesis stand accepted.

\section{DISCUSSION}

\section{Hypothesis 1-}

Data shows that there is a negative relationship between time spent on TV viewing and creativity of high achiever student. Given the time high achiever student spent every day at home, this study found that children spent an average two hour and forty minutes on TV viewing per day. Findings from this study are consistent with the conclusive from Furu's $(1971)^{22}$, Wade's $(1971)^{23}$, Singer and Singer $\left(1981\right.$ b) ${ }^{24}$ and MacBeth's study (1966). Thus time spending in front of TV is associated with low creativity.

In addition, William (1986) ${ }^{25}$ has also concluded that the format and content of TV might not be optional for development of information-processing skills which facilitate creative thinking. He has argued that watching TV does not require children to elaborate. When tested in the form of print or writing and in problem solving skills, children may then be less willing to expand mental effort as they consume fantasies produced by others. Collins $(1983)^{26}$ also contends that the pace and format of TV make children develop "let you entertain me" orientation and discourage reflection, what is an important aspect of creative thinking.

\section{Hypothesis 2-}

R-value for this hypothesis is positive but not significant. It means for low achiever students there is a positive relationship between time spent on TV viewing and creativity. Some other researchers such as Beittei K R (1966) $)^{27}$, William P. A. $(1982)^{28}$, Seth, Indu (1983) $)^{29}$, Sudama and Goel $(1984)^{30}$, Mohanty $(1988)^{31}$, Kapadia A. M. $(1992)^{32}$ etc. explored that there is a positive 
relationship between television and academic achievement of students. Low achiever students considered those students that are backward in class. Television is helpful for low achiever students in gathering information. Pictures, Animations, Sounds etc. create a very fantastic environment for learning. A film, Cartoons, Motions affects student's imagination positively. Some TV shows can educate, inform and inspire. It can be more effective than books or lecture of teacher in teaching students about processes like how a plant grows and how our body systems work. So it can be said television enhance creativity and imagination of low achiever students. They make students to think in a different way.

\section{Hypothesis 3-}

Statistics of data show that there is a positive relationship between programs viewed on TV and creativity of high achiever students. Viewing some types of programs may provide students with benefits regarding creativity. Findings of this research support the notion that there is a positive correlation between viewing educational and / or children's programs, such as cartoons and children's verbal creativity test scores. Similar results were found in Singer and Singer's (1981 b) ${ }^{33}$ study in which boys whose play was most creative those who watched more comedies. Still some other observational studies Van Dar Voort and Valkenburg $(1994)^{34}$ show that children do use TV content in fantasy play, both during and after viewing. Once again, these findings indicate that program content or the types of programs viewed do matter. Moderate viewers of these programs, have higher verbal creativity score than heavy viewers, however relationship was not significant.

\section{Hypothesis 4-}

According to data it revealed that there is a positive relationship between numbers of programs and creativity but this relationship is not significant. The positive effect of viewing specific TV programs might by the stimulation hypothesis Valkenburg (2001) and the social learning theory (Bandura 1977, 1986, 2002). To children watching TV might be an active process in many ways similar to reading, during which information is selectively gathered. This may lead to improvement in the quality or quantity of creative products (Schneider, $(1987)^{35}$. Creative model have to be present in the TV programs for children to learn by example, so that they can draw a source of ideas for use in a fantasy play and activities involving creative thinking.

One possible interpretation can be that low achiever students watch programs on TV irrationally. In case of low achiever students television affects originality of students because during watching television student does not act. They become only passive audience. They become totally depend on which they see on television. Programs telecasts on television are almost imaginative when students watch than they do not need to imagine, so that originality of thinking of students suffers much more.

\section{Hypothesis 5-}

Data revealed that there is a positive relationship between numbers of channels viewed and creativity of high achiever students. The value of this relationship is not significant. Because high achiever students those who are very eager to gather information. TV has a wide impact on children mind. It might be argued that TV represents an important, easily accessible alternative to parental storytelling and spontaneous play. TV seems a good and cheap way to offer the opportunity for them to come in to contact with magic, fantasy and richer information about the world (Singer and Singer, 1981). Investigation about the influence of TV on creative and imaginative skills and children's play in the late 1970's are (Friedrich-cofer, Huston-stein, Kipnis, Susman and clewett 1979) ${ }^{36}$, (Singer and Singer 1976), (Singer and Singer 181 a \& b), (Tower and Singer, Singer and Biggs, $1979)^{37}$. These studies found out that specific types of programs such as child oriented programs or nonviolent adult drama might have a positive effect on creativity, especially if the viewing was moderated and mediated by an adult.

\section{Hypothesis 6-}

According to data there is a negative insignificant relationship between numbers of channels and creativity of low achiever students. Many researches have shown a negative correlation between low achiever students. Some other studies such as Howe $(1983)^{38}$ found that children's creativity is reduced when children spent plenty of their time on watching TV, at the expenses of other leisure activities, such as playing, reading and listening to radio. TV's reductive effect is not due to TV itself, but to the fact that it replaces other more beneficial activities. One other study supports this relationship. William $(1986)^{39}$ was able to examine the effects of TV viewing on the creativity of children and a group of adults. William compare three communities in Canada, labeled as Notel (a town by then has few regular TV medium), Unitel (having one TV channel) and Multitel (having several channels). In the cross sectional and longitudinal samples, creativity samples, creativity scores on the Alternative use task were negatively affected by TV viewing, by comparing the scores before and two years after TV was introduced in Notel.

\section{CONCLUSION}

There is no doubt that TV viewing has become an integral part of modern life and almost every child grows up watching some TV. Generally, information presented on TV seems to leave a deeper impression on children's mind, which explains why they may readily draw from elements in TV presentations. However, there appears to be no conclusive evidence suggesting that TV viewing adversely impact a child's ability to think imaginatively and creativity. Having said so, there is some support for the claim that TV viewing does not promote imaginative thinking. The results of this study 
are important but not dramatic. They will not verify a statement that television destroys creative ability. Indeed, there is a strong suggestion that television actually increases abilities but in some area it has negative effects. The results of this study do indicate that increasing amount of programs students watches or forcing exclusive categories of television production upon a child, will generally increase creative performance. Overall, research suggests that television viewing has a non significant positive relationship rather than a negative relationship on children's creativity.

\section{REFERENCES}

[1] SCHMIDT, MARIE EVANS and VANDEWATER, ELIZABETH A. (2008). "Media and Attention, cognition and school achievement. Future of children, Vol. 18, No.-1, pp-63-85 FROM www.futureofchildren.org

[2] KIRKORIAN, HEATHER L; WARTELLA, ELLEN A; and ANDERSON, DANIAL R. (2008). "Media and Young children are learning." Future of children, Vol. 18, No.-1, pp-39-61 FROM www.futureofchildren.org

[3] WYATT, LISA MARCEL (2006). "Racial differences in television watching, family context and reading achievement." Dissertation Abstracts International (A), The Humanities and social sciences, Vol. 66, No.-8, pp-3106A-3107A FROM Www.eric.org

[4] SHEJWAL, B.R. and PURAYIDATHIL, JOY (2006). "Television viewing of higher secondary students: Does it affect their academic achievement and mathematical reasoning." Psychology and developing societies FROM www.sagepublication.com

[5] ARYA, KALPNA (2004). "Time spent on television viewing and its effect on changing values of social going children." Antropologist, Vol. 6(4), pp-269-271 FROM www.google.com

[6] KROSRICK, JOHN A.; ANAND SOWMYA NARAYAN; HARTL, SCOTT P. (2003). "Psychological predictors of heavy television viewing among preadolescents and adolescents." Basic and Applied social psychology, Vol. 25(2), pp-87-110, Lawrence Eribaum Associates, Inc. FROM www.google.com

[7] HERSHBERGER, A. (2002). "The evils of television- The amount of television viewing and school performance level." Retrieved Jan. 2009 IN www.isub.edu/journal/2002/hershberger.

[8] TAJ, H. and MASTHAN, N.S. (1998) "Television: A spurt to modern perspectives of education." Psycho-lingua, Vol. 28(2), pp-167-169.
[9] KAUR, J. (1998). "Impact of viewing TV on the social life of rural illiterate and neo-illiterate adults." Psycho-lingua, Vol. 28(1), pp-39-44.

[10] AGARWALLA, SUNITA (1998). "A study of the educational impact of television on the social and moral development of the women in the Greater Guwahati area." Ph.D. Gauhati University, Gauhati IN Six surveys of researches in education, Vol. I, pp-156.

[11] PANDA, M. and YADAVA, R. (2005). "Implicity creativity theories in India: An Exploration." Psychological studies, Vol. 50(1), pp-32-39.

[12] ISEN, A. M. (2000), "Positive affective and decision making" IN M Lewis and J Haviland. Editors, Handbook of Emotions, Guilford, New York IInd edtion.

[13] KAILE, HARNEK and PUNIA, TEJINDER KAUR (1994). "Relationship between creativity and socio-economic status." Experiment in Education, Vol. 22(2), pp-35-39.

[14] RAJ, H. SANADA (1994). "Fluency, flexibility and Originality as correlates of intelligence." The Creative Psychologist, Vol. 6(1\&2), pp-25-30.

[15] CHAURASIA, OMKAR (1993). "Family functioning and creative abilities." Perspective in Psychological Research, Vol. 16(1\&2), pp-61-63.

[16] SINGH, BANSH GOPAL (1993). “Creativity as a function of reinforcement oriented teaching strategy as perceived by pupils." Indian Journal of Psychometry and Education, Vol. 24(1), pp-31-36.

[17] PANDEY, R.C. and KHARKWAL, MEENA KUMARI (1993). "Creativity and socio-economic status." Perspective in Psychological Researches, Vol. 16(1\&2), pp-27-29.

[18] MARK, A. RUNCO and KATHY, PEZDET (2009). "The effect of television and radio on children's creativity." Human Communication Research, Vol. 11, Issue- 1, pp-109-120, International communication association FROM www.google.com.

[19] IU, KEYNE HAR YEE (2003), "Relationship between Hong Kong Children's creativity and their television viewing habits" From www.google.com

[20] SINGER, D. G. and SINGER, J. L. (2001), Handbook of children and the media, Thousands Oaks, Calif. Sage Publication.IU, KEYNE HOR YEE (2003). "Relationship between Hong Kong children's creativity and their television viewing habits." FROM www.google.com

[21] MACBETH, T.M. (1996). "Indirect effects of Television: creativity, persistence, school achievement and participation in other activities." "Tuning into young viewers: social science 
perspectives on Television, pp-149-219, Thousand Oaks, CA FROM www.sagepub.com

[22] FURU (1971) IN T. M. MacBeth (1996) "Indirect effects of television" IN T M MacBeth (Ed.) "Tunning in to Young viewers : Social science perspectives on Television" Thousand Oaks CA: SAGE pp-149-219.

[23] WADE, S. E .(1971) “Adolescence, creativity and media" American Behavioral Scientist Vol. 14, pp341-351 FROM www.sagepub.com/journal'sreprints.nav

[24] SINGER, J. L. and SINGER, D. G. (1981) "Television, Imagination and aggression: A study of preschoolers" Hillsdale NJ: Lawrance Erlbaum.

[25] WILLIAM, T. M. etal. (1986) "The impact of Television: A Natural Experiment in three communities." Academic Press Ins.

[26] COLLINS, W. A. (1983) "Interpretation and inference in children's television viewing" IN J. BRYANT \& D.R. ANDERSON (Eds.) Children's understanding of television: Research on attention and comprehension. New York, Academic Press. pp-125-150.

[27] BEITTEI, K .R. (1966) "Instructional media for creativity in the arts" Instructional Media and Creativity. Edited by C Taylor, New York, John Willey and sons.

[28] WILliAM, P. A. , HAERTEL,E. H., HAERTEL, G. D. and WALBERG, H. J. (1982) "The impact of leisure-time television on social learning: A Research synthesis" American Educational Research Journal (19) pp-19-50 IN Media and Young children's learning (2000) FROM www.futureofchildren.com

[29] SETH, INDU (1983) "A study of effectiveness of educational television on the educational development of primary school children" Ph.D. Education, Maharaja Sayojiro University of Baroda IN Fourth survey of researches in education, NCERT.

[30] SUDAMA, G. R. and GOYAL, D. R. (1984) "Students and school TV program" Experiment in Education. 12(10). Pp-174-180.
[31] MOHANTY, P. C. (1988) "A critical study of the educational television program for the primary school children in Orissa." Ph.D. Education Utkal University IN Fifth survey of researches in education. Vol.-11, pp-1382, NCERT.

[32] KAPADIA, A. M. (1992) "The impact of television on student's learning: An exploration" Ph.D. Education, South Gujrat University IN Fifth survey of education, Vol.II, pp-1371, NCERT

[33] Ibid

[34] VAN, DER VOORT and VALKENBURG, P. M. (1994) “Television's impact on fantasy play: A review of research." Development Review 14, pp27-51.

[35] SCHNEIDER, C. (1987) “Children's televisionThe art, the business and how it works." NTC Business book FROM www.eric.gov

[36] FREDRICH-COFER, L. K., HUSTON-STEN, A., KIPNIS, D. M., SUSMAN, E. J. and CLEWELL, A. S. (1979) "Environmental enhancement of prosocial television content: effects on interpersonal behavior, imaginative play and self regulation in Natural setting" Development Psychology (15), pp-637-646.

[37] TOWER, R. B., SINGER, D. G., SINGER, J. L. and BIGGS, A. (1979) "Differential effects of television programming on preschooler's cognition, imagination and social play." Orthopsychat, (49), pp-265-271.

[38] HOWE, M. J. A. (Eds.) (1983) "Learning from television: psychological and educational research" London Academic Press Ltd.

[39] WILLIAM, T. M. etal. (1986) "The impact of Television: A Natural Experiment in three communities." Academic Press Ins.

Dr. Ravi Kant is an assistant professor in Education at the College of Teacher Education, Darbhanga, Maulana Azad National University. Dr. Kant received his PhD degree in Education from the Mahatma Jyotiba Phule Rohilkhand University, Bareilly. $\mathrm{He}$ is a member of IATE. He authored a book "Television and Creativity" published by Lambert Publishing House, Germany. 